\title{
KIPRAH UMKM DITENGAH KRISIS EKONOMI, PERANNYA BESAR, MINIM PERHATIAN PEMERINTAH
}

\author{
Muchlis \\ Dosen Universitas Bunda Mulia, Jakarta
}

\begin{abstract}
Abstrak: Unit usaha mikro kecil dan menengah di Indonesia (Depkeu : 2005) diperkirakan 42,39 juta meliputi: usaha mikro 41,1 juta unit $(97,0 \%)$, usaha kecil 1,2 juta unit $(2,85 \%)$, usaha menengah 63.500 unit $(0,15 \%)$ dan usaha besar 4.200 unit $(0,61 \%)$. Dari 99,9 persen unit usaha adalah usaha mikro dan kecil. Tingkat penyediaan tenaga kerjanya 99,5 persen dan kontribusi terhadap GDP (Gross Domestic Product) $57 \%$. Sayangnya partisipasi UMKM terhadap perdagangan global baru $19 \%$ dari total ekspor nasional.
\end{abstract}

Kata Kunci: Usaha Mikro Kecil dan Menengah, perekonomian Indonesia

\section{UMKM Katup Pengaman Krisis Ekonomi}

Krisis ekonomi di Indonesia telah memberikan suatu catatan penting tentang performa ekonomi Indonesia. Perekonomian Indonesia ternyata dikuasai sektor korporasi, sedangkan pilar pembangunan ekonomi lainnya seperti usaha kecil dan menengah tidak dapat berbicara banyak. Ketika terjadinya krisis terbukti sektor korporasi ini tidak bisa bertahan dengan baik. Sebaliknya, UMKM yang tadinya kurang berperan dalam perekonomian Indonesia ternyata terbukti lebih mampu bertahan menghadapi gejolak perekonomian yang mengarah pada krisis multidimensi tersebut. Berbasis daya tahan sektor UMKM tersebut, pemerintah kemudian melahirkan paradigma mengembangkan sektor ini dengan lebih serius.

Sayangnya hingga kini partisipasi UMKM di tatanan ekonomi nasional dan internasional masih terganjal pada persoalan-persoalan klasik. Yang lebih menyedihkan, peran pemerintah untuk memajukan UMKM sangat minim. Meski telah dibuat skema kredit UMKM, tidak lebih dari lips service. Pengusaha masih sulit untuk mendapatkan modal kerja karena tidak memiliki agunan yang cukup. Persoalan klasik tidak pernah selesai.

Persoalan klasik yang masih dialami oleh sektor ini, penulis mengelompokkannya ke dalam beberapa persoalan mendasar. Di kelompok pertama, menyangkut kekurangan modal sebagai kendala sektor UMKM untuk maju. Terdapat beberapa faktor yang mendasar yang menyebabkan kurangnya daya serap UMKM terhadap ketersediaan kredit lunak yang disiapkan perbankan, antara lain tersedianya dana untuk pemenuhan persyaratan pengajuan kredit ke perbankan. Selain itu minimnya pengetahuan dalam penulisan proposal bisnis juga menghambat penyerapan kredit lunak yang disediakan perbankan.

Kelompok kedua, metode produksi yang masih tradisional dianggap melemahkan sektor UMKM untuk bersaing, terutama dalam memenuhi kebutuhan pasar internasional. Memasuki AFTA dan APEC bahwa sektor UMKM akan menghadapi tantangan yang semakin besar bila tidak segera mencari jalan keluar terhadap persoalan produksi. Terlebih hampir sebagian besar UMKM tidak memiliki sumber daya manusia yang dibutuhkan untuk bisa mengakses pasar internasional. Umumnya UMKM bergantung pada perusahaan trading yang sekaligus berfungsi sebagai pedagang pengumpul dan meraup laba sebanyakbanyaknya dari selisih harga. Belum lagi lemahnya dasar hukum UMKM di Indonesia. Jika ada UMKM yang berbadan hukum, seperti usaha dagang, CV, dan PT, tetapi tidak didukung dengan corporate governance yang baik.

Terkait dengan persoalan-persoalan yang dihadapi UMKM ini, bahwa telah ada serangkaian strategi untuk mewujudkan daya saing UMKM. Beberapa strategi antara lain memberikan prioritas berdasarkan peluang pasar, kapasitas produksi, dan pendekatan cluster, memperbaiki kualitas SDM UMKM dalam teknologi produksi, manajemen, pemasaran, dan kewirausahaan. Strategi yang telah dilontarkannya itu, telah pula diimplementasikan kedalam beberapa kebijakan, yang meliputi promosi dan pemasaran, pengembangan teknologi tepat guna untuk meningkatkan produksi dan penyediaan informasi.

Saat ini juga sudah dilakukan kerja sama luar negeri yang bertujuan untuk meningkatkan akses pasar UMKM di pasar internasional. Dalam pemasaran produk UMKM dilakukan kerjasama melalui lembaga perdagangan luar negeri seperti House of Indonesia. Menyadari diperlukan usaha yang serius dan sungguh-sungguh agar tercipta UMKM yang mandiri. Mandiri dalam artian mampu menyediakan SDM yang 
profesional, memiliki market share, memproduksi produk yang berkualitas, menggunakan teknologi, dan bisa memiliki permodalan yang lebih rasional.

\section{Globalisasi UMKM}

Gejala globalisasi ekonomi yang cepat, serta dalam upaya menghadapi era perdagangan bebas, diperlukan sebuah sinerji dalam upaya meningkatkan kemampuan untuk menciptakan pasar dan memperluas market share.

UMKM memiliki daya saing kuat untuk menghadapi pasar global, memiliki karakteristik spesifik seperti : memiliki tingkat kebebasan keluar-masuk pasar, sangat adaptif terhadap kebutuhan konsumen, kegiatan bisnis biaya relatif rendah, menjalankan fungsi sebagai prece takers dan product markets. Ditopang dengan langkah-langkah terobosan pemerintah untuk memberdayakan UMKM yang dapat dilakukan : (Edi Putra : 2005) :

1. Penyederhanaan perijinan, penerapan sistem satu pintu (bukan satu atap)

2. Penyelarasan aturan pemerintah pusat-daerah

3. Penghapusan berbagai peraturan (pusat dan daerah) yang memberatkan UMKM, misalnya pungutan dan distribusi daerah.

4. Efektifitas implementasi MOU Pemerintah dan $\mathrm{BI}$, dukungan pembiayaan untuk UMKM, untuk perluasan kredit mikro.

5. Perluasan sumber pendanaan untuk UMKM

6. Pengembangan pendidikan dan latihan bagi UMKM (entrepreneurship center)

Keterlibatan UMKM dipasar global, maka UMKM dikelompokkan menjadi (APEC: 2003) :

1. UMKM yang sudah masuk pasar global

Kelompok ini telah menjadi subkontrak dari perusahaan multi nasional terutama disekitar otomotif dan elektronik (8-13\% dari seluruh UMKM).

2. UMKM yang sudah/pernah masuk pasar global

Kelompok ini sudah mengekspor tetapi atas dasar pesanan luar negeri, tetapi memiliki potensi yang besar (14-17\% dari seluruh UMKM)

3. UMKM yang belum pernah melakukan transaksi luar negeri, tetapi memiliki potensi yang besar ( $25 \%$ dari seluruh UMKM).

4. UMKM yang memang tidak ada orientasi ke pasar global (50 \% dari seluruh UMKM).

Perkembangan bisnis global pada saat ini tidak lepas dari perkembangan teknologi yang demikian pesatnya. Batas-batas bisnis dan perdagangan antar negara seakan tidak lagi dibatasi jarak dan waktu, karena teknologi informasi telah menjawab kendala tersebut. Kemajuan teknologi informasi memungkinkan untuk membangun sebuah sistem yang dapat mendukung terjadinya suatu jaringan ekonomi kelayakan berbasis UMKM dalam rangka mengembangkan pemberdayaan dan sosialisasi ekonomi kelayakan di Indonesia.

Peningkatan pengetahuan, penguasaan dan pemanfaatan teknologi informasi bagi UMKM seiring dengan maraknya perniagaan dengan memanfaatkan teknologi internet yang melahirkan konsep ecommerce yang telah menjadi sebuah model baru bagi dunia bisnis global.

Dalam globalisasi UMKM di Indonesia sangat diharapkan sebagai salah satu faktor utama pendorong perkembangan dan pertumbuhan ekspor non migas dan sebagai industri pendukung membuat komponen-komponen untuk usaha besar. Oleh sebab itu harus membenahi diri agar dapat menghasilkan daya saing global.

\section{REFERENSI}

Edi Putra (2005), Seminar Kebijakan Pemerintah Dalam Pembiayaan UMKM dan Koperasi, Jakarta, 2005.

Tulus Tambunan (2002), UMKM di Indonesia, Jakarta: Salemba Empat

Hidayat (2002), Seminar UKM, Jakarta.

Undang Undang Nomor 9 Tahun 1995 tentang Usaha Skala Kecil. 